\title{
20
}

\section{KiwiSaver: A jewel in the crown of New Zealand's retirement income framework?}

\author{
Kirsten MacDonald and Ross Guest
}

\section{Retirement income policy design}

New Zealand is a relative newcomer to the world of national superannuation vehicles to support private saving. In 2007, just before the GFC, New Zealand implemented KiwiSaver-a voluntary superannuation system to sit alongside the government pension, New Zealand Superannuation (NZS). Being a small nation in the South Pacific has never stopped New Zealand from standing out from the crowd. Whether in rugby union, the America's Cup or economic reform, the world has watched with interest because New Zealand is seen to be doing things differently and often winning. Retirement income policy is no exception, with the innovation of automatic enrolment in KiwiSaver among other distinctive features of its design. The examination of retirement income policy in the current context of ageing populations, pressure on government budgets in terms of social support, the need to increase self-funding for retirement and the shift of risk and decision-making to individual investors enables us to learn from successful policy design and implementation in the face of challenges and the need for adjustment over time in response to changing environmental conditions. 
Based on the World Bank's (1994) three-pillars approach, New Zealand's retirement income policy is primarily based on a tax and transfer 'payas-you-go' (PAYG) system, including a unique near-universal flatrate pillar-one pension. Since 2007, NZS has been complemented by KiwiSaver-a hybrid, Pillar 2/3 scheme. KiwiSaver is funded by a mix of individual and employer contributions plus a government subsidy known as member tax credit. KiwiSaver members are automatically enrolled on starting new employment, although they can opt out or take contribution holidays. Membership is not limited to those in employment, so even children can join. Savers also have the option to make additional voluntary contributions and to hold other forms of voluntary private savings outside KiwiSaver. Table 20.1 summarises the design features of the New Zealand retirement income system as of April 2018.

Table 20.1 Summary of design features of the New Zealand retirement income system in 2018

\begin{tabular}{|c|c|}
\hline \multicolumn{2}{|c|}{ The pillars } \\
\hline Pillar 1 & $\begin{array}{l}\text { NZS, a universal pension, funded from PAYG. The New Zealand } \\
\text { Superannuation Fund was established in } 2001 \text { to commence partial } \\
\text { funding of NZS from } 2020 \text {. }\end{array}$ \\
\hline Pillar 2 & $\begin{array}{l}\text { KiwiSaver is a hybrid of Pillar } 2 \text { and Pillar } 3 \text { schemes. Minimum employer } \\
\text { contributions is a Pillar } 2 \text { feature, and the employee opt-out, along with } \\
\text { optional higher contribution rates, is a Pillar } 3 \text { feature. }\end{array}$ \\
\hline Pillar 3 & $\begin{array}{l}\text { Voluntary private superannuation separate from KiwiSaver. Taxation is the } \\
\text { same as for KiwiSaver. No private saving tax incentives. }\end{array}$ \\
\hline \multicolumn{2}{|c|}{ Public pension } \\
\hline Eligibility & Age 65 , subject to residence test ${ }^{a}$ \\
\hline Amount & $\begin{array}{l}\text { Singles } \\
42 \% \text { of } 2016 \text { median weekly wage/salary } \\
\text { Approximately } 40 \% \text { of average national income (male and female) } \\
\text { per beneficiary } \\
\text { Couples } \\
32 \% \text { each of } 2016 \text { median weekly wage/salary }\end{array}$ \\
\hline $\begin{array}{l}\text { Means } \\
\text { testing }\end{array}$ & None \\
\hline Taxation & Taxable at marginal rate \\
\hline
\end{tabular}




\begin{tabular}{|c|c|}
\hline \multicolumn{2}{|c|}{ Private pension (superannuation) } \\
\hline $\begin{array}{l}\text { Minimum } \\
\text { contribution } \\
\text { rates }\end{array}$ & $\begin{array}{l}\text { Employer contribution } \\
\text { Minimum 3\% of gross earnings } \\
\text { Employee contribution } \\
\text { Minimum and default rate } 3 \% \text { (optional rates } 4 \% \text { or } 8 \% \text { ) of gross earnings } \\
\text { Applies to employees aged } 18-65 \text { but employers may choose to } \\
\text { continue to contribute for employees aged } 65+ \\
\text { A contribution holiday cannot be taken in the first year of membership } \\
\text { without evidence of financial hardship. Beyond the first year, can apply for } \\
\text { between three months and five years without providing a reason, renewing } \\
\text { the holiday at any time or taking an unlimited number of future contribution } \\
\text { holidays. Employer contributions also cease during this period. }{ }^{\circ}\end{array}$ \\
\hline Taxation $^{d}$ & $\begin{array}{l}\text { Employer contribution } \\
\text { Employer superannuation contribution tax is charged at rates from } 10.5 \% \\
\text { to } 33 \% \text { depending on marginal tax rates applicable to prior years' earnings } \\
\text { Employee contribution } \\
\text { Employee contributions made from after-tax income (i.e. already taxed at } \\
\text { marginal rate), thus no cap on contributions } \\
\text { Superannuation fund earnings } \\
\text { Widely held superannuation funds: } 28 \% \\
\text { Portfolio investment entities: applicable prescribed investor rate, ranging } \\
\text { from } 10.5 \% \text { to } 28 \% \\
\text { Withdrawals } \\
\text { Available at age } 65 \text {, tax-free }\end{array}$ \\
\hline Withdrawals & $\begin{array}{l}\text { Homeownership } \\
\text { Funds including employee, employer, member tax credits and associated } \\
\text { returns are accessible for owner-occupied housing purchases subject to } \\
\text { eligibility requirements and minimum balance of } \$ 1,000 \text { after withdrawal } \\
\text { Decumulation phase } \\
\text { KiwiSaver members able to continue to invest or withdraw beyond age } 65 \\
\text { with little restriction, including lump-sum or regular withdrawals with low or } \\
\text { no minimum withdrawal per transaction depending on a particular fund's } \\
\text { rules. No default annuity products but can be purchased in the market. } \\
\text { Less-developed market for annuities and home equity release products. }\end{array}$ \\
\hline
\end{tabular}

a For New Zealand residence requirements, see Ministry of Social Development (n.d.).

${ }^{b}$ These figures are calculated from the 2016 median New Zealand weekly earnings of NZ\$924 (A\$883) and maximum after-tax weekly 2016 pension payments of NZ\$384.76 (A\$367.66) (Statistics NZ 2018).

${ }^{c}$ As of June 2017, approximately 5 per cent of the membership base is on contribution holidays, the majority of which are over 60 months in length (IRD 2017).

${ }^{d}$ For taxation of superannuation in New Zealand, see IRD (2019a).

e See IRD (2019b).

Source: Adapted from Guest (2013). 


\section{A policy success?}

The addition of KiwiSaver to New Zealand's retirement income framework in 2007 can be considered both a process and a political success. KiwiSaver has been remarkably successful in signing up New Zealanders for retirement saving, despite its voluntary nature. Although there were political challenges at the outset and through periods of political upheaval, multiparty support has enabled the hard yards to be achieved in terms of streamlining reporting and transparency for investors and providing strong governance in the KiwiSaver market. Nonetheless, from a programmatic standpoint, the results are mixed. New Zealand has shown the world how to implement an administratively cost-effective system through the existing tax platform. But, according to a seven-year multiagency KiwiSaver evaluation steering group-incorporating members from the Ministry of Business, Innovation and Employment, the Treasury, the Commission for Financial Capability, the Financial Markets Authority, the Ministry of Social Development, Victoria University of Wellington, Statistics New Zealand, the Inland Revenue Department and research companies and contractors-KiwiSaver has been marginally successful at best in achieving its policy goals in the short term, with limited evidence to support wealth accumulation (IRD 2015).

KiwiSaver was launched with a set of highly criticised government incentives. Those who stood to benefit the most were likely to be those already saving elsewhere rather than KiwiSaver's target cohort, who might struggle to save despite the incentives. The seven-year evaluation and reporting process had the purposes of providing evidence of the effectiveness of KiwiSaver when considered against the objectives of the policy: to encourage a long-term savings habit and asset accumulation by individuals who are not in a position to enjoy standards of retirement similar to those in preretirement, to increase individuals' wellbeing and financial independence, particularly in retirement, and to provide retirement benefits. While the scheme was successful in exceeding membership targets, only one-third of KiwiSaver members are from the target group (IRD 2015). Political change has led to fiscal restraint being applied over time to unwind the inbuilt benefits. However, the conclusion of the evaluation program echoes the initial political and financial services concerns over KiwiSaver in terms of social inclusion and the participation 
of low-income earners. Those who have benefited the least from KiwiSaver to date are typically young, low-income and low net worth, less educated singles and renters (Colmar Brunton 2010; IRD 2015).

The following sections unpack the programmatic, procedural and political perspectives of the addition of KiwiSaver to New Zealand's retirement income framework. An analysis of how different design features impact on success and to what extent policy objectives are achieved is followed by consideration of political perspectives on KiwiSaver and its policy journey through time.

\section{Programmatic assessment}

The design features of both the public and the private components of the New Zealand retirement income system have public policy implications for retirement outcomes and the fiscal cost of the system. The Commission for Financial Capability (CFFC 2010) identified eight policy objectives that influence how public policy on retirement income systems is designed. ${ }^{1}$ This section assesses the programmatic success of the KiwiSaver program against the policy objectives of income support, citizenship dividends, fiscal restraint, voluntary saving, cohort self-funding, wellbeing, longevity risk-pooling and lifetime consumption smoothing, with the common economic success factors in the evaluation of retirement income policy being equity, stability, sustainability, adequacy and economic efficiency.

\section{Equity}

Equity can be measured both between and within generations and is impacted by both KiwiSaver and NZS. Intergenerational equity can be thought of in terms of the burden on the current workforce to contribute towards the cost of government pensions for the retired population. The fiscal implications of NZS - essentially an intergenerational social contract and an unfunded pension liability due to the PAYG nature of the scheme-are volatile costs due to changes in the age structure of the population (CFFC 2010). The ratio of the working-age (15-64 years) to retired (65 years and over) population is expected to halve in New Zealand between 2013 and 2060 (Coleman 2015), creating a high

1 The Commission for Financial Capability was formerly known as the Commission for Financial Literacy and Retirement Income and, before that, the Retirement Commission. 
rate of cost-shifting between generations due to population ageing and a universal rather than means-tested age pension. However, an increasing degree of cost-shifting to future generations does not always lead to intergenerational inequity.

Numerous factors, both monetary and nonmonetary, impact intergenerational equity and offset the negative economic consequences of the increasing cost of government pensions. From the suffragette movement to war efforts and the general innovation and investment of prior generations, current and future generations benefit not only in standards of living, but also in higher incomes (Gemmell 2017). At a reasonable projected long-run labour productivity growth of 1.5 per cent per annum and accounting for an increase in tax to cover increasing government pensions, average disposable incomes can be expected to be 70 per cent higher in 30-40 years (Guest 2013), improving the opportunities for cohort self-funding via KiwiSaver to reduce future intergenerational equity concerns. Moreover, Gemmell (2017) identifies that baby boomers have little effect on New Zealand's long-term dependency ratios, with the persistent ageing problem more strongly related to health care and other advances impacting on longevity. While current workers may pay more collectively to support the baby boomers, they are likely to live longer themselves and receive government pensions for longer, even if they retire somewhat after age 65. Gen X and Gen $Y$ are also more likely to inherit wealth from their families, but some within a generation may fare better than others.

Intragenerational equity considers the welfare of those within a generation. Prior to and beyond the introduction of KiwiSaver, NZS has been successful in achieving a lower rate of poverty in the over-65 population in New Zealand than in most of the world (OECD 2016). Guest (2013) suggests this is evidence of a stronger correction in the New Zealand retirement income system for income inequality experienced at a younger age. NZS provides income support for almost all of the over-65 population. Those with lower working-life incomes seem relatively better off in retirement, but NZS provides a poor level of income replacement for middle to high-income earners. The provision of NZS to those who are financially well off may be viewed as less equitable than in other countries, but equity is coloured by philosophical views of NZS, which may even impact attitudes towards KiwiSaver. 
NZS can be thought of as a citizenship dividend that treats the productive efforts and contributions made by citizens from all walks of life equally, providing the same recognition and entitlement from the age of eligibility and removing any stigma associated with applying for targeted welfare (CFFC 2010). In this regard, the universal nature of NZS provides a positive impact on social cohesion compared with means-tested age pensions that may have a more divisive impact on the eligible community. On the other hand, those who view government support as an entitlement rather than a safety net are more likely to view personal savings through voluntary savings vehicles such as KiwiSaver as additional to requirements and have different spending priorities. They are also more likely to game the system where there is the opportunity to do so in a means-tested regime (Stephen 2016). NZS gets the balance about right, with a payment sufficient to cover the essentials, large enough neither to incentivise early retirement or large spending to collect it nor to lead the public to believe it is enough to live on. As incomes rise and NZS does, too, the indexation rate may need to be reconsidered for both behavioural reasons and sustainability.

\section{Sustainability}

The New Zealand retirement income system is vulnerable in terms of sustainability despite the addition of KiwiSaver and even after the removal of many of KiwiSaver's inbuilt incentives. The sustainability of current settings in relation to NZS in the face of demographic change and the impact on fiscal costs has been questioned. Although they are difficult to predict in the long run, the fiscal costs of the government pension are expected to grow as the number of retirees grows and this is compounded by the universal nature of NZS. From an administrative cost perspective, New Zealand performs among the best in the OECD (OECD 2011). KiwiSaver achieves operational efficiencies through the use of the income tax platform, lower tax concessions and no access to tax-free withdrawals until age 65, resulting in a percentage of GDP cost of only 0.35 for KiwiSaver (Guest 2013). However, the sustainability of policy choices also concerns the cost of borrowing. All else being equal, net debt in New Zealand is projected to rise to 69 per cent of GDP by 2045 (The Treasury 2016). Strategies are in place to manage unfunded public pension liabilities related to NZS after 2020, which will ease the need for future borrowing, although it is unlikely the New Zealand Superannuation Fund will be accessed so soon. 


\section{Stability}

KiwiSaver has experienced frequent change over one decade in contrast with the relative stability of NZS since 1990-although changes are expected in a young system over time to get things right and NZS has previously experienced periods of high instability (see, for example, Littlewood 2008). However, both possible and actual policy changes to retirement income systems impact on stability. There has been ongoing debate regarding an increase in the age of eligibility for NZS, a return to means testing for NZS and whether or not KiwiSaver ought to be compulsory, among other issues. For example, evidence shows that individuals and employees consider the possibility of KiwiSaver changing or being discontinued as a major barrier to joining (IRD 2015). The downside of cumulative change and perceptions of future change impact on attitudes and behaviours in relation to retirement saving and spending, with flow-on effects to the achievement of policy objectives and other success factors such as adequacy.

\section{Adequacy}

KiwiSaver strengthens an individual's ability to derive an adequate income from the New Zealand retirement income system, but there is still much room for improvement. Adequacy concerns how well the combined total of income from government pensions and private accumulated wealth cover meets retirement needs. NZS ensures low poverty rates in the over-65 population in New Zealand, but poverty (financial deprivation) is a very low level of support, particularly for medium to high-income earners (OECD 2017). Superannuation and other assets can be used to bring overall retirement income up to a desired level of income replacement - often in the range of 65-95 per cent, but typically 70 per cent of preretirement earnings. Survey evidence from New Zealand reveals that individuals are generally aware of their needs in retirement, but actual savings fall well short of target savings (ASB Bank 2012). Half of those surveyed expect to fall short of a comfortable retirement and onethird are concerned they will not even meet basic needs (Law et al. 2011). Although NZS is universal, differences in the design of private savings vehicles such as KiwiSaver are what have greater impact on the adequacy of retirement income. 


\section{Cohort self-funding}

In New Zealand, the KiwiSaver coverage rate of 58 per cent of the total population is a relative success given the voluntary nature of the scheme (IRD 2017; Statistics NZ 2018). KiwiSaver opt-out statistics remain high, at approximately 30 per cent of automatically enrolled membersequivalent to about 12 per cent of the gross membership base. One-third of opt outs are due to affordability issues, with slightly less related to the belief there are better financial alternatives (IRD 2015). The distinguishing characteristic of KiwiSaver members who opt out is their level of income, with the majority earning less than $\$ 30,000$-well below the mean and median gross earnings for KiwiSaver members and a number that generally reflects the New Zealand wage and salary population. Opt-outs are spread relatively evenly across age groups and most report being in full-time work with low net worth (Colmar Brunton 2010; IRD 2015). Adequacy is less of a concern for the majority of opt-outs, with NZS providing the strongest replacement rate for low-income workers. For those remaining in the scheme, contribution rates and asset allocation are the key to accumulating wealth to support retirement adequacy.

KiwiSaver offers a range of 3 per cent, 4 per cent or 8 per cent contribution rates for employees. Yet, the majority of KiwiSaver members have a joint employer-employee contribution rate of 6 per cent of gross earningsthe default contribution rate (IRD 2016). Taking no action or choosing the lowest contribution rate can be expected to significantly impact superannuation balances, especially given the very conservative asset allocations under KiwiSaver, including legislative restrictions to have no more than 25 per cent growth assets in default funds. The average superannuation balance in 2013-14 was NZ\$8,000 (A \$7,600) in KiwiSaver (IRD 2017). Given KiwiSaver is a young scheme that includes children and those not in the workforce, it makes more sense to consider a representative individual on average earnings throughout their working life and the combined retirement income from KiwiSaver and the age pension. The representative individual is expected to achieve a level of preretirement income replacement rates of approximately 60 per cent (MacDonald et al. 2012); however, income distributions are skewed to the right and not all assets to fund retirement are held as financial assets.

An analysis of asset holding in New Zealand reveals a preference for investment in real assets including businesses and farms. This is not surprising due to the voluntary nature of KiwiSaver and the short time 
frame over which it has been running. The flexibility of KiwiSaver allows members to go on a contribution holiday and redirect funds to consumption or alternative investments. This has been seen as a negative feature in terms of the impact on future superannuation balances. However, in compulsory systems, individuals often borrow for current consumption and thus adjust the amount of their savings or adjust the mix of their assets-for example, by purchasing property, with the intention to repay later from superannuation balances (Guest 2013). The potential impact may be more significant in New Zealand with the opportunity to borrow without necessarily having continuing superannuation contributions locked in as an asset for offset. It is clear, however, that governments have more control over the form of saving than over the amount of saving, calling into question the net welfare benefit added by mandatory superannuation given the associated costs.

Retirement adequacy is also impacted by demographic differences, which impact salaries and wages and patterns of work, which in turn impact on the size and continuity of superannuation contributions. KiwiSaver data show a direct correlation between income and contributions, with males contributing more than females and Māori contributing the least of all members identifying as being from a non-European background (IRD 2015). Females fare better in New Zealand than other nations in terms of the gender superannuation gap as a result of a smaller gender pay gap (Guest 2013), but the strength of this finding is limited due to the New Zealand balances excluding other saving sources of retirement saving. Also, wealth accumulation in KiwiSaver was for a five-year period-a time frame unlikely to provide insights into patterns of periods off work, for example, due to parent and carer roles often undertaken by women. Other asset holdings may also favour males due to small business ownership and workplace superannuation schemes in effect many decades prior to the introduction of KiwiSaver. Across the Tasman, Bianchi et al. (2016) identified significant retirement gaps for Indigenous Australian males (27 per cent lower) and females (39 per cent lower) compared with a median non-Indigenous male worker. Such studies point to the broader policy framework on education and employment to strengthen New Zealand working life incomes to improve adequacy.

The ability to examine the assets available for retirement alone and consider their potential to create income is limited given the choices individuals exercise in investing and borrowing outside superannuation and their approach to drawdown and consumption in retirement. Home 
equity may be accessed through reverse mortgages or downsizing and some assets are not yet accounted for, such as transfers of intergenerational equity. The design features of KiwiSaver that provide an element of choice-such as withdrawal for homeownership, opt-outs for those automatically enrolled and contribution holidays - score highly in terms of nonmonetary aspects of wellbeing. However, when combined with a low default contribution rate and more conservative asset allocation, New Zealanders need to carefully consider their choices to strengthen their retirement adequacy. Future cohort analysis may reveal more detailed insights, and further investigation needs to be done to support those who stand to benefit the least from national superannuation programs.

\section{Longevity risk-pooling}

Even if individuals accumulate sufficient wealth with the potential to improve retirement outcomes, they may deplete their superannuation balances too soon for many reasons, including underestimation of their own longevity, increasing debt to repay in ageing households, healthcare shocks, costs of aged care, market conditions and, in means-tested systems such as Australia's, spending fuelled by moral hazard. NZS acts like a lifetime annuity and provides similar degrees of longevity risk-pooling. Government pensions are effective in longevity risk-pooling because they are inflation-protected annuities from the age of eligibility until the end of life (Commission for Financial Literacy and Retirement Income 2012). But the problem remains the lack of longevity protection for private superannuation.

The New Zealand Government has realised the problem created by the relative lack of attention to and control over the decumulation phase of private superannuation versus the accumulation phase. In countries such as New Zealand, where annuitisation is voluntary, annuities have not been popular-hampered by the unfavourable nature of the tax system. New Zealand has a poorly developed market in which supply-side problems further restrict choices due to private sector unwillingness to assume longevity and inflation risks without effective hedging opportunities (Berthold 2013). Economists and market commentators have called for the development of a generic government-managed annuity decumulation product to exploit the best attributes of KiwiSaver and the potential to include long-term care provisions (St John 2014). Nevertheless, even with government support for the decumulation of private superannuation, government pensions will continue to play a central role in individuals' portfolios. 
Empirical evidence highlights the role of government pensions in providing flexibility in portfolio management and protection against changing market conditions. Not only is compulsory annuitisation likely to be highly unpopular, but also Pfau (2013) shows that the combination of financial assets with annuities is more successful to support individuals' trade-offs for minimum spending needs, lifestyle goals and unexpected contingencies. To the extent that there is likely to be a long implementation phase should any changes occur to NZS, a guaranteed income source such as NZS provides KiwiSaver members with some volatility protection to enable them to take a less conservative investment position and adjust their rate of withdrawal from superannuation as required (Finke et al. 2011). Although New Zealand has been shown to have one of the highest safe withdrawal rates in the world (Drew and Walk 2014; Pfau and Dokken 2015; Blanchett et al. 2016) — that is, the rate of drawdown from the portfolio while avoiding portfolio ruin-investors with low accumulated balances (less than $\$ 200,000$ ), particularly those in conservative investments, face a 'no frills' retirement even when combining regular KiwiSaver withdrawals with NZS. Long-run lower future market return expectations mean that NZS is important even for those with larger KiwiSaver balances $(\$ 350,000$ to $\$ 500,000)$ who would also face significant adjustments to standards of living should they have reduced access to or funding from NZS through future changes, particularly in the face of increased retirement horizons (MacDonald 2016).

\section{Economic efficiency}

Economic efficiency considers the wider social and economic effects of retirement income policy such as labour participation and employment, labour productivity, saving incentives, lifetime consumption smoothing and wellbeing.

\section{Labour participation and productivity}

Increasing labour participation and productivity is an effective approach to reducing the fiscal costs associated with ageing populations. KiwiSaver and NZS provide strong incentives to work. New Zealand reports high labour participation rates across all age groups, including the over-65 population (ILO 2011). The addition of KiwiSaver has impacted the cost of employment, but at a lower level than in other countries with higher employer contribution rates. Not being able to access either NZS or KiwiSaver until age 65 means only those with additional private savings 
are likely to retire early, with those who leave the workforce prior to age 65 due to health or unemployment reasons able to access welfare support. Labour productivity has a more complex relationship with retirement income policy. It is difficult to determine the impact of factors from the retirement income system or even the overall direction of the impact (for full analysis, see Guest 2013).

\section{Savings}

Although economic indicators show that New Zealand household and national savings are low against international standards, evidence that suggests New Zealanders are saving enough highlights the problems with different approaches to measuring saving (Orr and Purdue 2001; Le et al. 2009). It is difficult to determine the net effect on saving in New Zealand, with both positive and negative effects from NZS and KiwiSaver, but overall it is likely to be positive. KiwiSaver's opt-out provision is limited to a small set of members - those over the age of 18 who were automatically enrolled on commencing new employment. This has a negative effect on household savings, along with contribution holidays, which have no limits on time or the number of holidays taken. Despite the choice of higher contribution rates ( 4 or 8 per cent), the majority of members who do not opt out invest at the minimum and default rate (IRD 2015). Possible reasons include a lack of cash flow, the universal nature of NZS or investor inertia or myopia, with only half of KiwiSaver members rating themselves somewhere between neutral and highly engaged (Colmar Brunton 2010). On the positive side, KiwiSaver does not require a member to be in employment so even children can be encouraged to participate with a view to impacting saving behaviour in the long term across the whole population. But those with small balances or on a contribution holiday risk the erosion of their savings from fees while small or no contributions are made. A further negative effect is moral hazard-the unintended consequence of relatively generous government pensions such as NZS that reduce the need to save for retirement.

\section{Lifetime consumption smoothing}

The elements of choice regarding when and how to save can assist with proper balancing of spending and saving during the different phases of one's life. KiwiSaver members are also provided with welfare advantages, to the extent that their choices are 'rational' and based on their financial circumstances. However, the favourable tax environment for housingwith no capital gains tax or stamp duty-means the incentives for saving 
are stronger for investment in housing, particularly with either the optout or withdrawal for homeownership provisions available in KiwiSaver or even a contribution holiday while paying down student loan debt or borrowing for housing. The choice to spend on housing - a less liquid asset-is not necessarily problematic in terms of retirement outcomes. Poverty rates in New Zealand are much higher for those renting, so homeownership impacts positively on wellbeing during working life and retirement (IRD 2015; OECD 2016).

\section{A summative assessment}

Table 20.2 summarises the programmatic assessment of the addition of KiwiSaver to the New Zealand retirement income system. Together, NZS and KiwiSaver strengthen the system, which stands out for its intragenerational equity, choice, flexibility, incentives to work and administrative simplicity. Importantly, where one component is negative, the two components of the system have an offsetting effect. Table 20.2 identifies weaknesses in the system as cohort self-funding and fiscal costs. The evaluation is simplistic, with the assumption of equal weighting of economic success factors and policy objectives and inclusion of subjective measures, equity and wellbeing. For the long-term success of the system, more attention needs to be paid to the design of KiwiSaver and NZS to support adequacy and sustainability.

Table 20.2 Programmatic evaluation: Performance against success factors and policy objectives

\begin{tabular}{|l|c|c|c|c|c|}
\hline \multirow{2}{*}{$\begin{array}{l}\text { Success factor/policy } \\
\text { objective }\end{array}$} & \multicolumn{2}{|c|}{ Australia } & \multicolumn{2}{c|}{ New Zealand } & Which system \\
\cline { 2 - 5 } & $\begin{array}{c}\text { Age } \\
\text { pension }\end{array}$ & SG & NZS & KiwiSaver & \\
\hline Intergenerational equity & $\checkmark$ & $\mathrm{n}$ & & $\mathrm{n}$ & Australia \\
\hline Intragenerational equity & & & & & NZ \\
\hline Income support & $\checkmark$ & $\mathrm{n}$ & $\checkmark \checkmark$ & $\mathrm{n}$ & \\
\hline Citizenship dividend & $\checkmark$ & $\mathrm{n}$ & $\checkmark \checkmark$ & $\mathrm{n}$ & \\
\hline Stability & $\checkmark$ & $\mathrm{x}$ & $\checkmark \checkmark$ & $\mathrm{x}$ & NZ \\
\hline Sustainability & & & & & Australia \\
\hline Fiscal restraint ${ }^{b}$ & $\checkmark$ & $\mathrm{x}$ & $\mathrm{x}$ & $\mathrm{n}$ & \\
\hline Adequacy & & & & & Australia \\
\hline Cohort self-funding & $\mathrm{x}$ & $\checkmark \checkmark \checkmark$ & $\mathrm{x}$ & $\checkmark \checkmark$ & \\
\hline Longevity risk-pooling & $\checkmark \checkmark \checkmark$ & $\mathrm{n}$ & $\checkmark \checkmark \checkmark$ & $\mathrm{n}$ & \\
\hline
\end{tabular}




\begin{tabular}{|l|c|c|c|c|c|}
\hline \multirow{2}{*}{$\begin{array}{l}\text { Success factor/policy } \\
\text { objective }\end{array}$} & \multicolumn{2}{|c|}{ Australia } & \multicolumn{2}{c|}{ New Zealand } & Which system \\
\cline { 2 - 5 } & $\begin{array}{c}\text { Age } \\
\text { pension }\end{array}$ & SG $^{a}$ & NZS & KiwiSaver & \\
\hline Economic efficiency & $x$ & $\checkmark$ & & $\checkmark$ & NZ \\
\hline Voluntary saving & $x$ & $\checkmark$ & $x$ & $\checkmark \checkmark$ & \\
\hline Wellbeing & $\checkmark$ & $\checkmark \checkmark$ & $\checkmark \checkmark$ & $\checkmark \checkmark$ & \\
\hline $\begin{array}{l}\text { Lifetime consumption } \\
\text { smoothing }\end{array}$ & $x$ & & & $\checkmark$ & \\
\hline
\end{tabular}

$\checkmark \checkmark \checkmark$ strong

$\checkmark \checkmark$ moderate

$\checkmark$ limited or weak

$x$ negative

n neutral

a Superannuation Guarantee

b In contrast to the approach of the Commission for Financial Capability (CFFC 2010), labour market effects are included under the wellbeing objective.

Note: This table summarises the strengths and weaknesses of components of the retirement income systems in New Zealand and Australia relative to each success criterion and policy objective based on the discussion.

Source: Adapted from Guest (2013).

\section{Process and political assessment}

New Zealand governments as early as 1898 established government pensions and explored ways to encourage private retirement savings (Preston 2001). However, it was not until 1975-in what looked like an early version of KiwiSaver-that any significant progress was made. The Labour Party established a short-lived (37 weeks) compulsory superannuation scheme with a combined employee-employer contribution rate to be phased in at up to 8 per cent of earnings (Preston 2001). But - in what is now considered one of the largest election bribes of all time and a major shift in public spending that some might describe as 'intergenerational theft' - the National Party promised a very generous government pension (equivalent to 80 per cent of the average ordinary wage for couples from age 60 from 1978), won the election and ended the compulsory superannuation scheme (George 2010). Tinkering with retirement income policy to adjust fiscal costs to economic conditions continued through successive governments, yet it would be almost 30 years until another Labour government would introduce a major policy change to seek to address private retirement savings. 
The original design of KiwiSaver, as per the 2005 Budget announcement, implemented automatic enrolment for new employees aged 18-65, with the ability to opt out, employee contributions at either 4 per cent (the default level) or 8 per cent of gross earnings, boosted by government payments of a one-off tax-free $\$ 1,000$, an annual $\$ 40$ fee subsidy and any voluntary additional employee contributions (IRD 2008). Employers were eligible for an exemption from the employer superannuation contribution tax for employer contributions up to a maximum of 4 per cent of an employee's gross pay (IRD 2016). In introducing the KiwiSaver Bill to parliament, the policy's political champion, Labour finance minister Michael Cullen, announced there had been extensive consultation and already some changes, but six main features remained: automatic enrolment to tilt the playing field towards long-term savings; savings locked in until retirement; choice for members in how their funds are managed; minimum compliance costs for employees, employers and providers; prudential oversight; and the ability for existing schemes to join in and encouraging homeownership (New Zealand Parliament 2006a).

At the first reading of the Bill, there was a mixture of support and concern. Opposition parties raised issues such as: 1) no scheme being able to solve the problems underlying New Zealand's savings deficit; 2) concerns about the mixed purpose of KiwiSaver incorporating home deposit savings; 3) the likelihood that the $\$ 1,000$ kickstart payment would 'lose its glow' over time; and 4) a strong desire to focus on taxation reform and freedom of choice so people could access money when they needed it-particularly those with shorter lifespans (New Zealand Parliament 2006a). National Party leader John Key felt it was unconscionable to require households to compromise on their needs when KiwiSaver would not help those with an inability to save due to low incomes. Rather than a savings problem, it was a problem with productivity, social welfare, overtaxation and infrastructure bureaucracy that could not be solved by KiwiSaver (New Zealand Parliament 2006a). The political concerns that KiwiSaver could not resolve undersaving and the unclear purpose of and inconsistencies within the scheme (housing versus retirement) were echoed from the business and financial services communities. The Retirement Policy and Research Centre proposed economic growth as the only practical approach to managing the impact of an ageing population (New Zealand Parliament 2006c).

It was argued that KiwiSaver was a high-cost solution to a savings problem for which there was insufficient evidence (Gibson and Le 2008; Yong and Cox 2008). There was significant scrutiny of incentives, including the 
cost of government and employer contributions, and design features, such as the opportunity to withdraw funds for first-home purchases and questions about whether these incentives would be effective in creating new savings (Toder and Khitatrakun 2006; St John 2007; Yong and Cox 2008; Le et al. 2009; St John et al. 2014). There were further concerns about the potential effects of KiwiSaver in relation to NZS and equity. In 2007, Treasury and the Retirement Commissioner warned that the cost and inequity of KiwiSaver would have implications for the sustainability of NZS. The substitution of existing savings for KiwiSaver was expected to undo some of the equity created by NZS (St John 2007; Le et al. 2009). A 40-year-old KiwiSaver member on a high income could end up with $\$ 100,000$ to $\$ 150,000$, or 33 per cent of their accumulated wealth, at age 65, funded by taxpayers (St John 2008). Taxpayers and employers would carry the cost burden and employees and fund providers would enjoy the benefits (Yong and Cox 2008).

A last-minute change to KiwiSaver-against select committee recommendations - was the addition of a mortgage diversion facility, allowing up to 50 per cent of employee contributions to be paid into a mortgage after one year of membership (St John 2007). The facility was described as 'policy on the hoof', squeezed in just four hours before the second reading of the Bill, and was criticised for being rejected previously due to insufficient time to conduct analysis. The opposition parties did not support turning a savings account into a costly cheque account. Their focus remained on low-income earners trying to save, which led to lobbying for a 2 per cent contribution entry point. Labour argued that 2 per cent was not enough to save for retirement and it would be too hard to administer small accounts. However, the mortgage diversion itself would leave only a 2 per cent contribution in KiwiSaver (New Zealand Parliament 2006b). A transitional arrangement to compulsory employer contributions would now also be allowed - for example, so employers and employees could split equally the minimum 4 per cent contribution of gross earnings (Mercer 2007). Concerns then turned to the issue of employers finding out this news so late in the debate. The unexpected impact of co-contributions in future wage round negotiations might lead to employees effectively paying for their own contributions (New Zealand Parliament 2006b).

By the third reading, only the National Party voted against the Bill (71 to 48). Low income and affordability were still major concerns, with nearly 2 million people on incomes of less than $\$ 25,000$ a year. National saw 
this as a problem if the assumption underlying system design and lack of savings was assumed to be inertia. Initially, National had not supported KiwiSaver due to the lack of incentives; now it was due to the design of the incentives. Cullen was criticised for having a longstanding position that savings incentives would not work in any form, realising at the last minute they were required and then rushing poorly designed incentives through (New Zealand Parliament 2006c).

Further changes to KiwiSaver included pushing back the implementation date, from 1 April to 1 July 2007, the introduction of a member tax credit (a dollar-for-dollar match up to $\$ 20$ a week or $\$ 1,042.86$ per annum), compulsory employer contributions to be phased in evenly over four years (increasing from 1 per cent on 1 April 2008 to 4 per cent on 1 April 2011) and an employer tax credit ( $\$ 20$ per week up to $\$ 1,042.86$ per annum per employee in KiwiSaver) to partially offset the costs of compulsory employer contributions (Toder and Khitatrakun 2006; Gibson and Le 2008). National, the major opposition party, did not agree that KiwiSaver would be effective in its current form, while a minor party, United Futures, looked forward to when, 'in 10 years' time private savings by New Zealanders may be, let us say, $\$ 100$ billion' (New Zealand Parliament 2006c: 4994).

Ten years on, KiwiSaver is almost halfway there, with $\$ 40$ billion in funds under management (Parker 2017a). Unfortunately, National's points of debate-that only 25 per cent of New Zealanders would have a 'serious' KiwiSaver account in five years and that New Zealand would be like Ireland with 92 per cent of accounts dormant or Singapore with empty accounts due to mortgage diversion (New Zealand Parliament 2006a, 2006b) - are reflected somewhat in the current state of KiwiSaver. The average balance is now just under $\$ 15,000$, the number of noncontributing members stands at 38 per cent, the number of members taking long contribution holidays is increasing and $\$ 601$ million has been withdrawn for housing (IRD 2015, 2017). In contrast, the factor that far exceeded expectations is participation in KiwiSaver-at 58 per cent of New Zealand's working population and 75 per cent of the total population (IRD 2017; Parker 2017b). However, there is criticism of the make-up of this membership.

Through its incentives, KiwiSaver has attracted a large group of members who already held non-KiwiSaver superannuation-dominated by highincome earners. The target investor group KiwiSaver sought to increase represents only about one-third of members who reported being unlikely 
or very unlikely to have saved via a vehicle other than KiwiSaver. The members of this target group are predominantly younger, have lower incomes and lower net worth and are less educated, single and renters (Colmar Brunton 2010). Very low-income earners (less than $\$ 30,000$ per annum) dominate those who opt out. Opting out can, however, be positive for the wellbeing of low-income earners and prevents poverty during their working lives compared with their post-retirement income from NZS (Gibson et al. 2008). Labour has gone on to drop its campaign for compulsory membership, recognising the challenge of disposable income (Parker 2017b).

\section{Endurance assessment}

Many changes have been made to KiwiSaver over the past 10 years to correct what could be argued to have been poor initial design or rushed policy or both. The ill-fated mortgage diversion was closed in 2009 due to complexity, lack of use and unnecessary compliance costs, among other issues (IRD 2009). Other changes were made to address high fiscal costs, equity issues and market inefficiencies. The National Party removed the $\$ 1,000$ kickstart in 2015 to save $\$ 125$ million over four years after $\$ 2.5$ billion had been spent over the previous eight years (NZ Herald 2015). Another notable change related to market reforms and governance of KiwiSaver, made possible by broad support from all parties for the review of fees and the introduction of standardised reporting legislation (New Zealand Parliament 2011, 2013). While operational and cost efficiencies are important, two key areas that have received less attentiondespite having the most impact on retirement outcomes-are contribution rates and asset allocation.

The way in which contributions are split between stakeholders (employees, employers and the government) has undergone a number of changes since KiwiSaver's inception on 1 July 2007. Early evaluation examined the drivers of and barriers to KiwiSaver membership and found the primary barrier to enrolment was the minimum 4 per cent contribution and default rate (IRD 2008: 26), reflecting the previous debate in parliament about the affordability of participation. In 2009, National introduced the 2 per cent contribution rate previously lobbied for by the Green Party under the Labour Government. Concerned by statistics that 3 per cent of employees had increased their contribution rates since joining but three 
times as many had reduced their contribution rate (Colmar Brunton 2010), the Savings Working Group (SWG 2011) submitted a proposal to the government to maintain the 2 per cent minimum contribution level, but return the default setting to 4 per cent. The National Government's 2011 Budget answered the call of the Savings Working Group for a return to a 6 per cent default rate but with equal 3 per cent shares between employers and employees - with the rationale of increasing the employee contribution to offset tax changes and halving the member tax credit to avoid debt and to support national savings.

In 2013, default fund asset allocation was considered as part of the scheduled default provider review. The National Government confirmed the continuation of the very conservative investment approach, imposing a maximum of 25 per cent equity in default funds. The decision was made on the basis that it was most appropriate while the government was making decisions about other people's money (New Zealand Government 2013). While KiwiSaver has been a political success in the longer term (unlike NZS), this decision highlights a weakness in the retirement income framework, reflecting rational behaviour for the government, but not necessarily the best interests of KiwiSaver members in the long run - a sentiment also echoed by Littlewood (2008). However, the decision to stick to the status quo was a case of damned if they do, damned if they don't.

\section{Concluding reflections}

The final-year evaluation report concluded that KiwiSaver had not only a limited effect on the accumulation of net wealth, but also potentially a negative impact due to the conservative nature of default schemes (IRD 2015). These results were during a period of reasonable market performance. Had New Zealand been affected more by the GFC, the findings might have been different. Default funds are often viewed as a government endorsement of the investment. A loss relating to an increase in investment risk would impact not only members' saving behaviourand therefore the likelihood of achieving the goals of KiwiSaver-but also investors' attitudes towards the government. With the majority of submissions and earlier government-initiated reviews conducted by the Capital Market Development Taskforce (2009) and the Savings Working Group (SWG 2011) calling for change, the decision to forgo 
the opportunity to adjust the strongest lever available to address adequacy was disappointing, particularly in light of the difficulties found in other markets relying on financial education strategies and investor engagement to shift investors from default funds to funds more appropriate for their circumstances.

Considering the findings from the procedural, political and programmatic perspectives together, it is clear that a stronger focus is needed on the most important aspect of retirement savings for KiwiSaver members: retirement outcomes. Important questions arise from the evaluation of the addition of KiwiSaver to the New Zealand retirement framework:

1. Is the weak evidence of programmatic success due to the approach taken in the evaluation? How does the seven-year time frame impact the analysis? Are there alternative approaches available?

The seven-year evaluation by the multiagency KiwiSaver evaluation steering group included a survey of members of the evaluation team. The survey results indicated a 'very good' result in terms of effectiveness and satisfaction. Importantly, the respondents felt the seven-year time frame for the evaluation was not long enough. The evaluation team members supported regular reviews of KiwiSaver moving forward to consider new challenges such as the decumulation phase. They also note that the current evaluation cannot be extrapolated to consider the success of KiwiSaver in five to 10 years (IRD 2015). The methodological approaches to pension finance applied in other markets (e.g. Blake et al. 2007; Basu and Drew 2010) offer insights into the future of KiwiSaver. Modelling retirement savings over a KiwiSaver member's working life highlights both the weaknesses and the opportunities in KiwiSaver's design (MacDonald et al. 2012; MacDonald 2016).

2. Is the weak evidence of programmatic success due to the design of KiwiSaver? Is KiwiSaver capable of increasing the ability for cohort self-funding and delivering retirement adequacy in conjunction with NZS as it is? What design changes or investor behaviour changes can improve retirement outcomes?

Table 20.2 reveals the importance of exploring improved adequacy in KiwiSaver to counterbalance the sustainability challenge of NZS in the future. Changes to contribution rates in KiwiSaver over time have not seen a shift from large numbers of KiwiSaver members contributing at the default contribution rate. Examining the passage of KiwiSaver through 
parliament reveals a strong theme of reform of the broader taxation and economic policy framework to facilitate the ability to live on and save from working-life incomes to improve the number of KiwiSaver members from the target cohort and increase contribution rates into the future, as seen in international markets as their retirement vehicles have matured. However, even if contribution rates increase, when modelling KiwiSaver investment over a 40-year savings horizon, making higher contributions to conservative KiwiSaver asset allocations may still lead to unattainable retirement goals (MacDonald et al. 2012).

While default funds have lower equity risk, they place investors at a much higher risk of shortfall in achieving their retirement target (Basu and Drew 2010; MacDonald 2016). KiwiSaver investors moving out of default and conservative investments into even a moderate fund can increase their retirement adequacy without substantially increasing their downside risk. Moderate and high-growth KiwiSaver funds offer the opportunity for New Zealanders to accumulate levels of wealth that, in conjunction with NZS, are expected to provide adequate retirement outcomes (MacDonald 2016). More growth-oriented portfolio choices are made by those given financial advice (Zhang 2014), but the number of New Zealanders seeking such advice is low, at about 20 per cent (Matthews 2013; Risk Info 2017). New Zealand needs to address investor engagement-specifically, issues such as myopia, procrastination and excessive risk-aversion in investment, often due to young people sitting in default funds with an asset allocation that may not be appropriate for their individual circumstances.

The relatively modest success of KiwiSaver towards its goals in the short term does not prevent the realisation of a programmatic success in the future. For KiwiSaver to be seen as an enduring procedural and political success, the most pressing concerns are consideration of further evaluation points and a political champion(s) to address adequacy. Issues of particular concern relating directly to retirement outcomes are default fund design and consideration of the decumulation phase to support the use of accumulated KiwiSaver wealth in conjunction with NZS to replace income in retirement. 


\section{References}

ASB Bank 2012. 'KiwiSaver contributions short of retirement savings goals.' Scoop, 13 June. Available from: www.scoop.co.nz/stories/BU1206/S00354/ kiwisaver-contributions-short-of-retirement-savings-goals.htm.

Basu, A. K. and Drew, M. E. 2010. 'The appropriateness of default investment options in defined contribution plans: Australian evidence.' Pacific-Basin Finance Journal 18: 290-305.

Berthold, T. 2013. Assuring retirement income. Working Paper 01/13. Wellington: Ministry of Social Development.

Bianchi, R. J., Drew, M. E., Walk, A. N. and Wiafe, O. 2016. 'Retirement adequacy of Indigenous Australians: A baseline study.' Economic Papers 35(4): 359-74. doi.org/10.1111/1759-3441.12154.

Blake, D., Cairns, A. J. G. and Dowd, K. 2007. 'The impact of occupation and gender on pensions and defined contribution plans.' The Geneva Papers 32: 458-82.

Blanchett, D., Serhan, A. and Gee, P. 2016. 'Safe withdrawal rates for Australian retirees.' Morning Star. Accessed from: www.morningstar.com.au/smsf/article/ withdrawal-rates/7529/2?q=printme (site discontinued).

Capital Market Development Taskforce 2009. Capital Markets Matter: Summary report of the Capital Market Development Taskforce. Wellington: Ministry of Business, Innovation and Employment. Available from: www.med.govt.nz/ business/economic-development/pdf-docs-library/cmd-capital-marketsmatter-exec-summary.pdf.

Coleman, A. 2015. 'Pension payments and receipts by New Zealand birth cohorts, 1916-1986.' New Zealand Economic Papers 50: 51-70. doi.org/10.1080/ 00779954.2015 .1095787$.

Colmar Brunton 2010. KiwiSaver evaluation: Survey of individuals_Final report prepared for Inland Revenue. Wellington: Inland Revenue Department. Accessed from: www.ird.govt.nz/resources/0/3/03e46600437177c5a25eb24 e9c145ab7/ks-evaluation-individuals.pdf (site discontinued).

Commission for Financial Capability (CFFC) 2010. 2010 Review of Retirement Income Policy. Wellington: CFFC. Available from: www.cffc.org.nz/assets/ Documents/RI-Review-2010-Full-Report.pdf. 
Commission for Financial Literacy and Retirement Income 2012. Longevity Risk Pooling. Wellington: Commission for Financial Literacy and Retirement Income. Available from: www.cffc.org.nz/assets/Documents/RetirementIncome-Position-Paper-4-Longevity-Risk-Pooling-2012.pdf.

Drew, M. E. and Walk, A. N. 2014. How safe are safe withdrawal rates in retirement? An Australian perspective. Research Report. Sydney: Financial Services Institute of Australasia. Available from: www.finsia.com/docs/ default-source/Retirement-Risk-Zone/how-safe-are-safe-withdrawal-rates-inretirement-an-australian-perspective.pdf? $\mathrm{sfvrsn}=2$.

Finke, M., Pfau, W. D. and Williams, D. 2011. Spending flexibility and safe withdrawal rates. Online paper, 8 November. doi.org/10.2139/ssrn.1956727.

Gemmell, N. 2017. Reforms to New Zealand Superannuation eligibility: Are they a good idea? Working Papers in Public Finance No. 08/2017, June. Wellington: Victoria Business School. Available from: www.victoria.ac.nz/_data/ assets/pdf_file/0003/909507/WP_08_2017_Reforms_to-_New_Zealand _Superannuation.pdf.

George, G. 2010. 'Laughable super comments.' Otago Daily Times, 24 December. Available from: www.odt.co.nz/opinion/laughable-super-comments.

Gibson, J. and Le, T. 2008. How much new saving will KiwiSaver produce? Working Paper in Economics No. 03/08. Hamilton, NZ: University of Waikato.

Gibson, J., Hector, C. and Le, T. 2008. The distributional impact of KiwiSaver incentives. Working Paper in Economics No. 02/08. Hamilton, NZ: University of Waikato.

Guest, R. 2013. Comparison of the New Zealand and Australian retirement income systems. Background Paper prepared for the 2013 review of retirement income policy by the Commission for Financial Literacy and Retirement Income. Auckland: Commission for Financial Capability. Available from: www.cffc.org.nz/assets/Documents/RI-Review-2013-Comparison-NZ-AusRetirement-Income-Systems.pdf.

Inland Revenue Department (IRD) 2008. KiwiSaver Evaluation: Annual report 1, 1 July 2007-30 June 2008. Wellington: IRD. Accessed from: www.ird.govt. $\mathrm{nz} /$ resources/0/4/04c0c6804bec321183fdab1877c64b2b/ks-evaluation 1.pdf (site discontinued).

Inland Revenue Department (IRD) 2009. Taxation (Budget Tax Measures) Act 2009: Closing the KiwiSaver mortgage diversion facility. Wellington: IRD. Available from: www.ird.govt.nz/technical-tax/legislation/2009/2009-14/leg2009-14-closing-ks-diversion.html. 
Inland Revenue Department (IRD) 2015. KiwiSaver Evaluation: Final summary report-A joint agency evaluation 2007-2014. February. Wellington: National Research and Evaluation Unit, IRD. Available from: www.ird.govt.nz/resources/ 3/8/38e71a99-51cd-4971-abb7-87ee68497b23/ks-evaluation-final-summaryreport.pdf.

Inland Revenue Department (IRD) 2016. KiwiSaver contributions. [Online]. Wellington: IRD. Available from: www.kiwisaver.govt.nz/already/ contributions/.

Inland Revenue Department (IRD) 2017. KiwiSaver statistics by year. [Online]. Wellington: IRD. Available from: www.kiwisaver.govt.nz/statistics/annual/.

Inland Revenue Department (IRD) 2019a. KiwiSaver and tax. [Online]. Wellington: IRD. Available from: www.kiwisaver.govt.nz/already/contributions/tax/.

Inland Revenue Department (IRD) 2019b. KiwiSaver benefits: Savings withdrawal to purchase your first home. [Online]. Wellington: IRD Department. Available from: www.kiwisaver.govt.nz/new/benefits/homewithdrawl/.

International Labour Organization (ILO) 2011. Key Indicators of the Labour Market (KILM). Geneva: Department of Economic and Labour Market Analysis, ILO.

Law, D., Meehan, L. and Scobie, G. 2011. KiwiSaver: An evaluation of the impact on retirement saving. New Zealand Treasury Working Paper. Wellington: The Treasury.

Le, T., Scobie, G. and Gibson, J. 2009. 'Are Kiwis saving enough for retirement? Evidence from SOFIE.' New Zealand Economic Papers 43(1): 3-19. doi.org/ 10.1080/00779950902803951.

Littlewood, M. 2008. A condensed history of public and private provision for retirement income in New Zealand: 1975-2008. In Pension Briefing: A briefing paper from the Retirement Policy and Research Centre. Auckland: University of Auckland Business School.

MacDonald, K. L. 2016. KiwiSaver and retirement adequacy. PhD thesis, Griffith University, Brisbane.

MacDonald, K. L., Bianchi, R. J. and Drew, M. E. 2012. 'KiwiSaver and retirement adequacy.' Australasian Accounting Business and Finance Journal 6(4): 61-78. Available from: ro.uow.edu.au/aabfj/vol6/iss4/5. 
Matthews, C. 2013. KiwiSaver and retirement savings in 2012. Report. Sydney: Financial Services Institute of Australasia. Available from: www.finsia.com/ docs/default-source/industry-reports-retirement-risk-zone/kiwisaver-andretirement-savings-in-2011.pdf?sfvrsn=9b41de93_4.

Mercer 2007. Recent KiwiSaver and Taxation Changes: Impact on employers and trustees. Auckland: Mercer New Zealand. Accessed from: www.superfacts.com/ files/MercerWealthSolutionNZ/document/20071219135044sjdierk7116.pdf (site discontinued).

Ministry of Social Development n.d. Residency requirements for New Zealand benefits and pensions: A guide to the residency requirements for New Zealand benefits and pensions. [Online]. Wellington: Ministry of Social Development. Available from: www.workandincome.govt.nz/pensions/travelling-or-moving/ moving-to-nz/residency-requirements-for-new-zealand-benefits-and-pensions. html\#null.

New Zealand Government 2013. KiwiSaver default provider review completed. Media release, 17 October. Wellington: New Zealand Government. Available from: www.beehive.govt.nz/release/kiwisaver-default-providerreview-completed.

NZ Herald 2015. 'Budget 2015: New KiwiSavers lose \$1000 “kick-start”.' NZ Herald, 21 May Available from: www.nzherald.co.nz/personal-finance/news/ article.cfm?c_id=12\&objectid=11452492.

New Zealand Parliament 2006a. New Zealand Parliamentary Debates (2 March) 629, 1673.

New Zealand Parliament 2006b. New Zealand Parliamentary Debates (24 August) 633, 4845 .

New Zealand Parliament 2006c. New Zealand Parliamentary Debates (30 August) 633, 4994.

New Zealand Parliament 2011. New Zealand Parliamentary Debates (7 April) 671, 17846.

New Zealand Parliament 2013. New Zealand Parliamentary Debates (27 August) 693, 12999.

Organisation for Economic Co-operation and Development (OECD) 2011. Pensions at a Glance 2011: Retirement income systems in OECD and G20 countries. Paris: OECD Publishing. doi.org/10.1787/pension_glance-2011-en. 
Organisation for Economic Co-operation and Development (OECD) 2016. OECD Data: Poverty rate. [Online]. Paris: OECD. Available from: data. oecd.org/inequality/poverty-rate.htm\#indicator-chart.

Organisation for Economic Co-operation and Development (OECD) 2017. Pensions at a Glance 2017: OECD and G20 indicators. Paris: OECD Publishing. doi.org/10.1787/pension_glance-2017-en.

Orr, A. and Purdue, D. 2001. Saving and investment in New Zealand, and the super fund. Westpac Institutional Bank Occasional Paper. Wellington: Westpac Institutional Bank.

Parker, T. 2017a. 'KiwiSaver hits \$40b, but balances stay low.' NZ Herald, 15 May. Available from: www.nzherald.co.nz/personal-finance/news/article. cfm?c_id=12\&objectid=11856222.

Parker, T. 2017b. 'Sir Michael Cullen: KiwiSaver should be mandatory.' $N Z$ Herald, 30 December. Available from: www.nzherald.co.nz/personal-finance/ news/article.cfm?c_id=12\&objectid=11884009.

Pfau, W. D. 2013. 'A broader framework for determining an efficient frontier for retirement income.' Journal of Financial Planning 26(2): 44-51.

Pfau, W. D. and Dokken, W. 2015. Rethinking retirement: Sustainable withdrawal rates for new retirees in 2015. White Paper. Bozeman, MT: WealthVest. Available from: www.fa-mag.com/userfiles/stories/whitepapers/2015/Wealth Vest_Sept_2015_Whitepaper/12040-Pfau-Sustainable-Withdrawal-RatesWhitepaper-.pdf.

Preston, D. A. 2001. Retirement Income in New Zealand: The historical context. Wellington: Office of the Retirement Commissioner.

Risk Info 2017. 'Client numbers fall despite increased demand for advice.' Risk Info, 1 November. Available from: riskinfo.com.au/news/2017/11/01/ client-numbers-fall-despite-higher-demand-for-advice/.

St John, S. 2007. 'KiwiSaver and the tax treatment of retirement saving in NZ.' NZ Economic Papers 41(2): 251-68. Accessed from: www.symposium.ac.nz/08/ filelibrary/KiwiSaver_tax_treatment_of_saving.pdf (site discontinued).

St John, S. 2008. 'Labour and National must agree to review KiwiSaver after the election.' NZ Herald, 13 October. Available from: www.nzherald.co.nz/ retirement/news/article.cfm?c_id=305\&objectid=10537308. 


\section{SUCCESSFUL PUBLIC POLICY}

St John, S. 2014. 'What has New Zealand's retirement policy framework got to offer the international debate?' Policy Quarterly 10(3): 29-34. Accessed from: apo.org.au/files/Resource/policyquarterly_nz-retirement-policy_2014.pdf (site discontinued).

St John, S., Littlewood, M. and Dale, M. C. 2014. Now we are six: Lessons from New Zealand's KiwiSaver. Retirement Policy and Research Centre Working Paper 2014-1. Auckland: University of Auckland Business School Retirement Policy and Research Centre.

Savings Working Group (SWG) 2011. Saving New Zealand: Reducing vulnerabilities and barriers to growth and prosperity-Savings Working Group final report to the Minister of Finance. Wellington: The Treasury. Available from: treasury.govt.nz/sites/default/files/2011-02/swg-report-jan11.pdf.

Statistics NZ 2018. NZ.Stat. [Online]. Wellington: Statistics NZ. Available from: nzdotstat.stats.govt.nz/wbos/index.aspx.

Stephen, E. 2016. Old age wealth decumulation in New Zealand. LLM Seminar Paper Laws 543: Elder Law. Wellington: Faculty of Law, Victoria University of Wellington. Available from: researcharchive.vuw.ac.nz/xmlui/bitstream/ handle/10063/5235/paper.pdf?sequence $=1$.

Toder, E. and Khitatrakun, S. 2006. Final Report to the Inland Revenue: KiwiSaver evaluation literature review. Washington, DC: Tax Policy Center. Available from: www.taxpolicycenter.org.

The Treasury 2016. He Tirohanga Mokopuna: 2016 statement on New Zealand's long-term fiscal position. November. Wellington: New Zealand Government. Available from: treasury.govt.nz/sites/default/files/2016-11/ltfs-16-htm.pdf.

World Bank 1994. Averting the Old Age Crisis: Policies to protect the old and promote growth. New York: Oxford University Press.

Yong, S. and Cox, N. 2008. The compliance costs of the KiwiSaver scheme. Presented to the Accounting and Finance Association of Australia and New Zealand Conference, Sydney, 6-8 July.

Zhang, A. C. 2014. 'Financial advice and asset allocation of individual investors.' Pacific Accounting Review 26(3): 226-47. 
This text is taken from Successful Public Policy: Lessons from Australia and New Zealand, edited by Joannah Luetjens, Michael Mintrom and Paul 't Hart, published 2019 by ANU Press, The Australian National University, Canberra, Australia.

doi.org/10.22459/SPP.2019.20 